- There is huge potential for techniques that can study the activity of large numbers of neurons for a long period of time with only minimal damage, says Jens Schouenborg, head of the Neuronano Research Centre at Lund University in Sweden, who has developed a gelatin-based 'needle' for delivering electrodes to the brain ${ }^{3}$. But he remains sceptical of this technique: "I would like to see more evidence of the implant's longterm compatibility with the body," he says.
Rigorous testing would be needed before such a device could be implanted in people. But, says Lieber, it could potentially treat brain damage caused by a stroke, as well as Parkinson's disease.

Lieber's team is not funded by the US government's US\$4.5-billion Brain Research through Advancing Innovative Neurotechnologies (BRAIN) initiative, launched in 2013, but the work points to the power of that effort's multidisciplinary approach, says Yuste, who was an early proponent of the BRAIN initiative. Bringing physical scientists into neuroscience, he says, could help to "break through the major experimental and theoretical challenges that we have to conquer in order to understand how the brain works". -

1. Liu, J. et al. Nature Nanotechnol. http://dx.doi. org/10.1038/nnano.2015.115 (2015).

2. Tian, B. et al. Nature Mater. 11, 986-994 (2012).

3. Lind, G., Linsmeier, C. E., Thelin, J. \& Schouenborg, J. J. Neural Eng. 7, 046005 (2010).

\title{
Start-ups fight for a place in Boston's biotech hub
}

\section{Competition for lab space threatens Kendall Square's innovative spark.}

\section{BY HEIDI LEDFORD}

A $s$ venture capitalist Kevin Bitterman gets ready to launch his latest start-up, he knows exactly where he wants it to be: Kendall Square, a densely populated neighbourhood in Cambridge and the heart of Boston's booming biotechnology industry. "You can't walk two feet there without seeing someone in biotech," he says. "That kinetic energy of having everybody squished together - it leads to a lot of advantages you can't get outside the city."

But Bitterman, a partner at the firm Polaris Partners in Boston, Massachusetts, finds himself contemplating the unthinkable: exile to the suburbs. Space in Kendall Square has always been tight, but now it is nearly impossible to find - particularly for young start-ups, he says. Two years ago, when he sought a home for another fledgling firm, Bitterman says he could count the options in the area on one hand. "But at least we had one hand of options to look at," he says. "There's literally nothing now."

The Boston-area biotech community is among the largest and densest in the world, with Kendall Square at its epicentre. The neighbourhood squeezes 120 biomedical firms within a 1.5 -kilometre radius. The density and diversity of the biotech ecosystem make Kendall unique, says Fiona Murray, associate dean for innovation at the nearby Massachusetts Institute of Technology (MIT) Sloan School of Management. The area is home to biomedical firms large and small, but also to the investors, patent lawyers, contract research organizations and suppliers they need to support them. "There's an extraordinary supply of human talent," says Murray.

But some say that the region may become

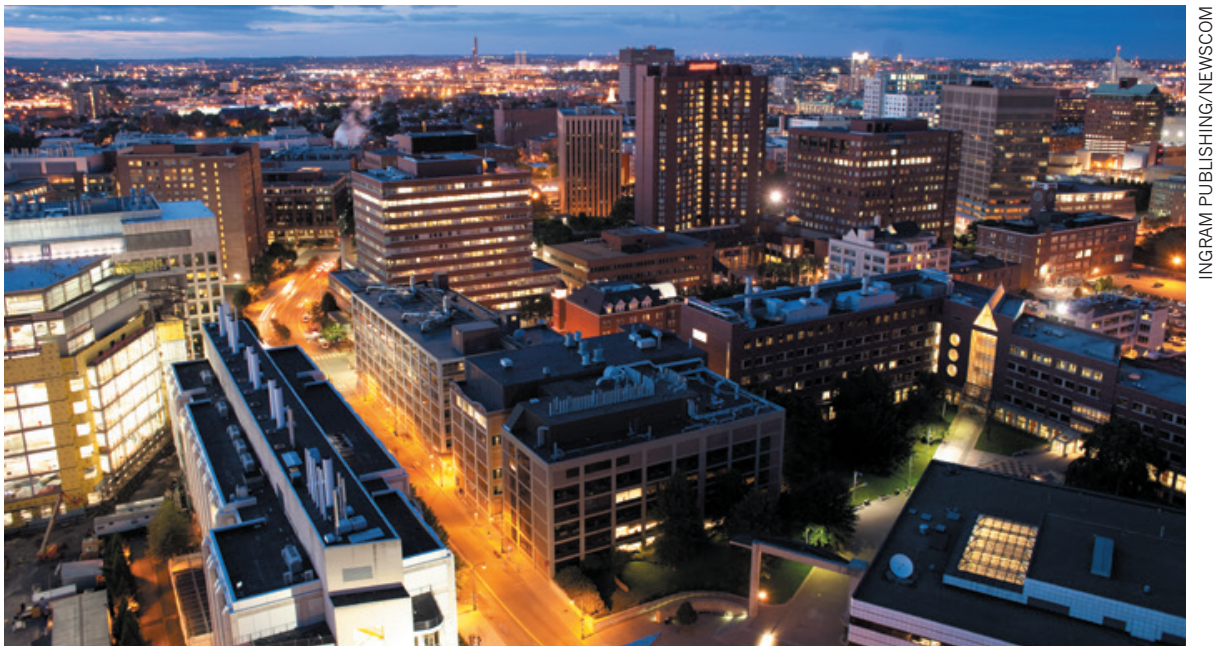

Technology and drug firms dominate the Kendall Square neighbourhood of Cambridge, Massachusetts.

a victim of its own success. Since the 1970s, Kendall Square has evolved from an industrial centre dotted with brick factory buildings into a hub of high-tech and biotech firms such as Biogen and Genzyme. Over the past five years, the technology giants Google and Microsoft and the multinational drug firms Novartis and Pfizer have dramatically expanded their offices and laboratories in the neighbourhood, eager to build close relationships with hot start-ups and the academic powerhouses of Harvard University and MIT. The influx threatens to squeeze out the start-up companies that have helped to make Kendall Square what it is. "There are so many benefits of being right here," says Chuck Wilson, who started the cancer-focused firm Unum Therapeutics in Kendall Square last year. The firm is growing so quickly that it will almost certainly need to leave the neighbourhood within months to get enough space.

At the same time, more-mature homegrown companies such as Alnylam Pharmaceuticals, which develops RNA-based therapies, and cancer-drug developer ARIAD Pharmaceuticals are expanding. "Companies that were only founded a couple of years ago are now gobbling up a lot of space," says Eric Smith, a partner in the Boston office of the commercial-property firm Transwestern.

Young biotechs also compete with high-tech firms so desperate for office space in Cambridge that they are renting buildings designed to accommodate labs. Since the end of 2012, lab rents in the Kendall Square area have risen by $13 \%$ to an annual rate of just over US $\$ 770$ per square metre (see 'Up and away'). Over the same period, annual office rents rose by $26 \%$ to just over $\$ 700$ per square metre. 
Alexandria Real Estate Equities, one of the largest owners of commercial lab space in the region, says that $99 \%$ of its Cambridge properties are occupied. In such a competitive market, most landlords will choose established tenants over potentially unstable start-ups. Although Cambridge has added 465,000 square metres of lab space since 2007, most of that has gone to large firms, says Peter Abair, director of economic development and global affairs at the Massachusetts Biotechnology Council in Cambridge.

\section{SHARED SPACES}

The local community recognizes that startups need to be nurtured for the biotech hub to thrive, says Peter Parker, a co-founder of LabCentral in Kendall Square. One of several local projects created to provide lab space and equipment to help start-ups get off the ground quickly, LabCentral receives state funding as well as corporate sponsorship from large pharmaceutical firms. It plans to double its occupancy in the next two years. MITIMCo, a division of MIT that manages the institution's sizeable property holdings, has also committed to housing start-ups.

But start-ups may disperse to the suburbs anyway, says José Lobo, who studies urban economies at Arizona State University in Tempe. Kendall Square's story is an anomaly, he says - urban centres around the world have tried to replicate it, mostly without success. And in places where biotech is thriving, such as the San Francisco Bay Area in California and the outskirts of Washington DC, it is more spread out. Having run out of affordable space in Kendall Square, Boston's biotech firms may soon follow that pattern, he says: "I won't be surprised if they leave."

Some already have. Wilson says that Unum Therapeutics is now close to signing a lease on the outskirts of Cambridge. He suspects that more will do the same, forming new start-up clusters in the suburbs. "We'll see how it evolves," he says. "But it'll be a very different feel." -

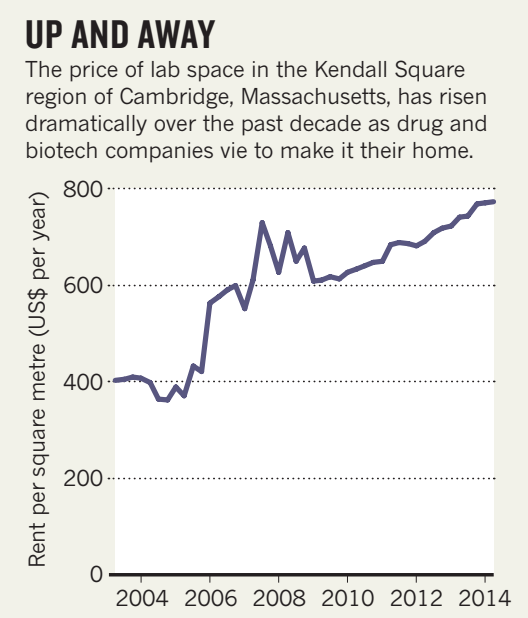

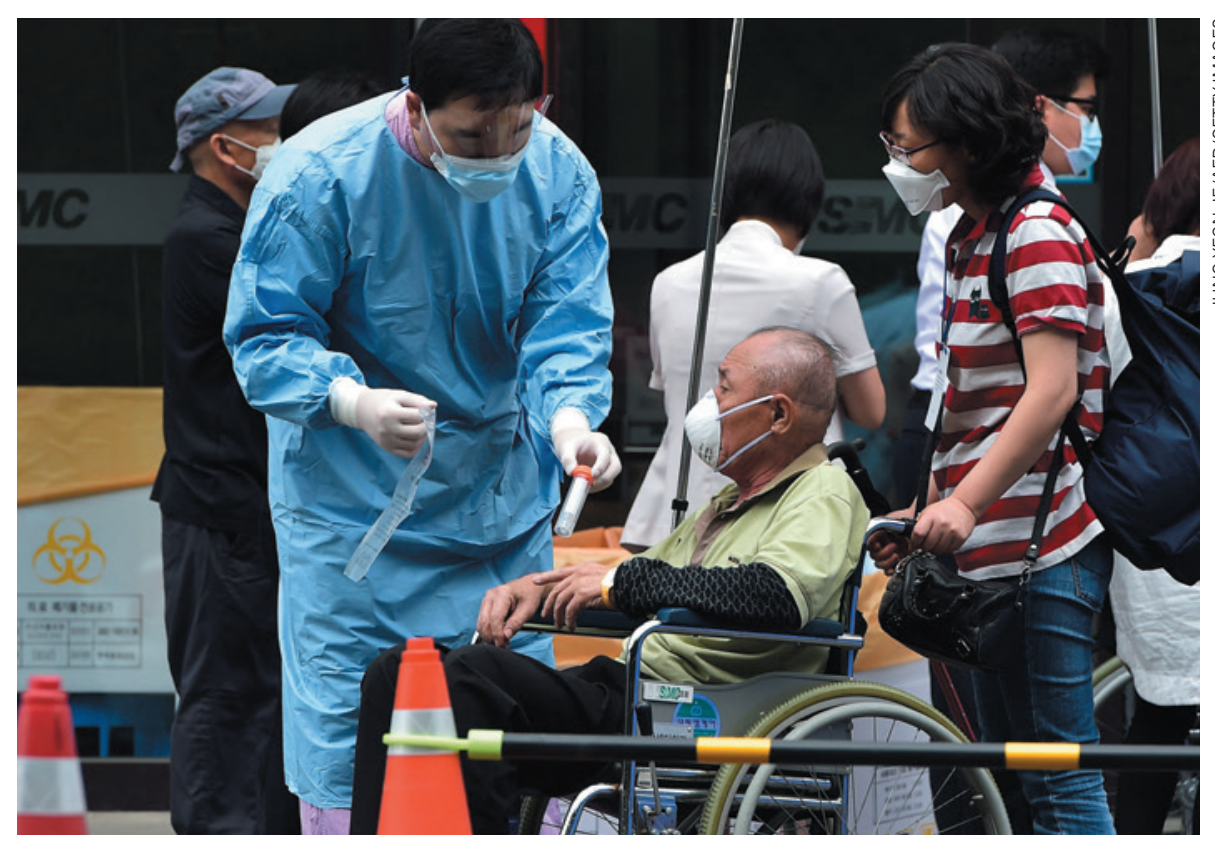

A medical worker in South Korea handles a sample from a man suspected of having the MERS virus.

SOUTH KOREA

\section{MERS cases spotlight lack of research}

\section{Outbreak of Middle East respiratory syndrome in South Korea is controllable, but how it infects humans is a puzzle.}

\section{BY DECLAN BUTLER}

I The world is watching South Korea as the latest outbreak of Middle East respiratory syndrome (MERS) unfolds. But how exactly the virus jumps to humans in the first place is still unknown, and clues to that puzzle lie thousands of kilometres away.

As Nature went to press, the cluster of hospital-associated cases in South Korea the largest MERS outbreak outside the Middle East - had killed 7 people and infected 95, according to the World Health Organization (WHO). Hundreds of schools have been shut. Although the causal coronavirus, MERS-CoV, is considered a potential pandemic threat, specialists told Nature that they expect authorities to quickly bring this outbreak under control.

A much bigger challenge than emergency response, they say, is how to stop MERS being transmitted from animals to people in the Middle East, where it is endemic in camels. "The focus on South Korea would be better directed towards Saudi Arabia," says David Heymann, a researcher at the London School of Hygiene and Tropical Medicine and chair of Public Health England, to stop the cases that continue to spark new outbreaks at the source. Since it was first detected in Saudi Arabia in 2012, MERS-CoV has infected around 1,200 people worldwide, roughly 450 of whom have died, according to the WHO. The virus is thought to originate in bats and to jump to humans through an intermediate animal, such as camels. It does not easily spread between people, partly because it infects deep areas of the lungs, and is not coughed out. Most of the human infections, however, were the result of human-to-human spread, which can occur in hospitals when certain medical procedures combine with poor infection control to disseminate the virus. The latest clusters began when a South Korean man returned to Seoul from the Middle East, and visited four health-care facilities before he was diagnosed.

There is always a chance that as the virus spreads, it could acquire mutations that allow it to spread more easily between humans. But on 6 June, the South Korean health ministry announced that it had sequenced the virus in the current outbreak and that it was almost identical to past sequences from the Middle East. On the same day, the Chinese Center for Disease Control and Prevention posted a 